\title{
Hubungan antara Penggunaan Antihipertensi pada Pasien Preeklamsia terhadap Insidensi Asfiksia Neonatal dan Berat Badan Lahir Rendah di RSUP Dr. Hasan Sadikin Bandung
}

\author{
Mutia F. Sitorus, Lia Amalia \\ Sekolah Farmasi Institut Teknologi Bandung, Bandung, Indonesia
}

\begin{abstract}
Abstrak
Preeklamsia merupakan satu dari tiga penyebab utama kematian ibu hamil di Indonesia. Selain menyebabkan mortalitas dan morbiditas maternal, bayi yang dilahirkan dari pasien preeklampsia berisiko lahir dengan berat badan lahir rendah (BBLR) $(<2500$ gr) dan asfiksia. Di Indonesia, data mengenai penggunaan antihipertensi tertentu sebagai lini utama pada terapi hipertensi dalam kehamilan serta dampaknya terhadap perinatal belum cukup memadai. Penelitian ini bertujuan untuk menggali hubungan dan pengaruh pemberian antihipertensi pada pasien preeklamsia terhadap outcome bayi (BBLR \& asfiksia). Penelitian dilakukan secara observasional terhadap 182 pasien preeklamsia yang dirawat di RSUP Dr. Hasan Sadikin Bandung selama tahun 2018. Dilakukan analisis komparatif antar kelompok antihipertensi dengan uji One-way ANOVA dan Kruskal-Wallis. Hasil analisis menunjukkan terdapat perbedaan rata-rata berat badan bayi yang bermakna secara statistik $(\mathrm{p}<0,05$; IK95\%) antara pasien preeklamsia yang mendapat terapi atihipertensi $(2227 \mathrm{gr} \pm 779,8)$ dengan pasien yang tidak mendapat terapi antihipertensi (2696 gr \pm 667,2). Tidak terdapat perbedaan skor Appearance, Pulse, Grimace, Activity, Respiration (APGAR) yang bermakna antara kelompok yang diberi terapi dengan tanpa terapi antihipertensi ( $>00,05$; IK95\%). Tidak terdapat perbedaan yang bermakna secara statistik $(\mathrm{p}>0,05$; IK95\%) antara beberapa kelompok terapi antihipertensi dalam memberikan kecenderungan terhadap kedua insidensi. Kelompok terapi kombinasi metildopa dengan antihipertensi lain (amlodipin, nikardipin, furosemid, dan spironolakton) memiliki proporsi tertinggi dalam memberikan kecenderungan terhadap insidensi BBLR $(75,0 \%)$ dan asfiksia $(17,9 \%)$.
\end{abstract}

Kata kunci: Antihipertensi, asfiksia, BBLR, preeklamsia, skor APGAR

\section{Association between Antihypertensive Treatment in Preeclampsia Patients with Incidence of Birth Asphyxia and Low Birth Weight at Dr. Hasan Sadikin Hospital Bandung}

\begin{abstract}
Preeclampsia is one of the three major causes of maternal death and morbidity in Indonesia. In addition, infants born are at risk of being born with a low birth weight/LBW $(<2500 \mathrm{gr})$ and asphyxia. In Indonesia, there is insufficient data regarding certain antihypertensive use as a first line therapy for hypertension in pregnancy and the consequent impact on perinatal. This study aimed to explore the association and effects of antihypertensive therapy in patients with preeclampsia on infants outcome (LBW \& asphyxia). The experiment was performed observationally on 182 preeclampsia patients treated at Dr. Hasan Sadikin Hospital Bandung in 2018. Furthermore, a comparative analysis was performed between antihypertensive groups using One-way ANOVA and Kruskal-Wallis tests. The result showed the existence of statistically significant differences in infant body weight $(\mathrm{p}<0.05$; CI95\%) between preeclampsia patients receiving antihypertension therapy (2227 gr \pm 779.8$)$ and those otherwise (2696 $\mathrm{gr} \pm 667.2)$. Moreover, there were no significant differences in Appearance, Pulse, Grimace, Activity, Respiration (APGAR) scores between the treated groups ( $>00.05$; CI95\%). The variations $(\mathrm{p}>0.05$; $\mathrm{CI} 95 \%$ ) between several units in line with the tendency to experience an incidence was not statistically significant. However, methyldopa therapy in combination with other antihypertensives (amlodipine, nicardipine, furosemide, and spironolactone) demonstrated the highest tendency towards LBW incidence $(75.0 \%)$ and neonatal asphyxia (17.9\%).
\end{abstract}

Keywords: Antihypertensive, APGAR score, asphyxia, LBW, preeclampsia

Korespondensi: apt. Mutia F. Sitorus, M.S.Farm., Sekolah Farmasi Institut Teknologi Bandung, Bandung, Jawa Barat 40132, Indonesia, email: seetofatma@gmail.com

Naskah diterima: 13 November 2019, Diterima untuk diterbitkan: 8 Desember 2020, Diterbitkan: 9 Desember 2020 


\section{Pendahuluan}

Hipertensi merupakan salah satu masalah medis yang paling umum dijumpai pada kondisi kehamilan dan merupakan penyebab utama morbiditas dan mortalitas maternal dan perinatal. ${ }^{1}$ Gangguan hipertensi masih menjadi masalah yang paling signifikan dan belum terselesaikan dalam lingkup keilmuan obstetrik. Gangguan hipertensi mempersulit 5-10\% dari seluruh kehamilan, serta dapat mengakibatkan perdarahan dan infeksi yang berkontribusi besar terhadap mortalitas dan morbiditas maternal. ${ }^{2}$

Preeklamsia merupakan komplikasi yang terjadi pada sekitar 2-8\% kehamilan dan dapat menyebabkan keadaan yang lebih buruk, termasuk eklamsia (preeklamsia yang disertai kejang), gagal ginjal, kelahiran prematur, hingga kematian. Preeklamsia merupakan gangguan pada kehamilan akibat berkurangnya perfusi darah ke organ yang menyebabkan vasospasme dan menurunnya aktivitas sel endotel. ${ }^{3}$

Beberapa data menunjukkan tingginya prevalensi kasus preeklamsia, salah satunya data World Health Organization (WHO) yang menyatakan sekitar $16 \%$ penyebab kematian ibu hamil di seluruh dunia disebabkan oleh gangguan hipertensi. Proporsi ini lebih tinggi dibandingkan tiga penyebab utama lainnya, yaitu perdarahan $(13 \%)$, aborsi $(8 \%)$, serta sepsis $(2 \%){ }^{2}$ Hasil evaluasi Millennium Development Goals (MDGs) mencatat sekitar 6400 kasus kematian ibu selama kurun waktu 2001-2015 dengan rasio 126 kasus/100.000 kelahiran. Data Profil Kesehatan Indonesia (2014) menyatakan tiga penyebab utama kematian ibu di Indonesia yaitu perdarahan, hipertensi dalam kehamilan (HDK), dan infeksi.

Riset Kesehatan Dasar (Riskesdas) 2013 menyatakan persentase angka kejadian berat badan lahir rendah (BBLR) di Jawa Barat mencapai 2,2\% dari keseluruhan jumlah bayi lahir yang ditimbang. BBLR terutama terjadi pada kelahiran prematur (yang disebabkan belum sempurnanya pertumbuhan sistem organ pada bayi). Kejadian ini dapat terjadi karena faktor genetik, kurangnya aliran darah menuju ke bayi atau disfungsi plasenta seperti preeklamsia. Asfiksia adalah keadaan darurat pada bayi yang tidak dapat bernapas spontan dan teratur sehingga menurunkan kadar oksigen dan meningkatkan karbondioksida yang memperburuk kehidupan lebih lanjut, dan merupakan penyebab kematian neonatal ketiga terbanyak (23\%) setelah kelahiran prematur (28\%) dan infeksi berat (26\%). ${ }^{4}$

Belum terdapat data yang memadai dalam penetapan satu kelompok antihipertensi tertentu yang dijadikan sebagai terapi lini utama hipertensi pada kondisi kehamilan. ${ }^{5}$ Pengalaman dalam pemilihan antihipertensi merupakan pertimbangan utama. Selama ini, antihipertensi yang diberikan pada kehamilan meliputi pemberian golongan Central $\alpha 2$ Agonists (Metildopa \& Klonidin), Calcium Channel Blocker (Nifedipin), Mixed $\alpha \&$ $\beta$-Blocker (Labetalol), dan Direct Arterial Vasodilator (Hidralazin). ${ }^{6}$

Penelitian sebelumnya di beberapa rumah sakit di Indonesia yang berkaitan dengan kasus preeklamsia, berfokus pada pembuktian hubungan antara preeklamsia dengan kejadian BBLR \& asfiksia neonatal. Namun, belum sampai pada pencarian hubungan pemberian antihipertensi pada pasien preeklamsia terhadap kejadian BBLR dan asfiksia.

Berdasarkan fenomena tersebut, dilakukan penelitian untuk menggali perbedaan pengaruh yang signifikan antara penggunaan beberapa antihipertensi pada pasien preeklamsia terhadap outcome bayi yang dilahirkan. Pemilihan BBLR dan asfiksia sebagai parameter outcome pembanding dilakukan dengan berdasarkan data Profil Kesehatan Dinas Kesehatan Jawa Barat (2017) yang menyatakan bahwa BBLR dan asfiksia merupakan komplikasi terbanyak kasus kematian bayi, terutama diakibatkan oleh kasus preeklamsia. 


\section{Metode}

Penelitian ini merupakan penelitian deskriptif observasional menggunakan rancangan crosssectional dengan pengambilan data secara retrospektif. Pengambilan sampel dilakukan terhadap pasien preeklamsia yang melakukan persalinan di RSUP Dr. Hasan Sadikin Bandung. Data pasien diperoleh dari rekam medik Departemen Obstetri dan Ginekologi RSUP Dr. Hasan Sadikin Bandung periode 1 Januari hingga 31 Desember 2018.

Penelitian ini berfokus pada penggalian hubungan antara profil penggunaan antihipertensi dengan outcome bayi yang dilahirkan, dan dievaluasi secara analitik. Pengamatan dilakukan dari pengukuran berat badan bayi saat lahir dan pengamatan skor Appearance, Pulse, Grimace, Activity, Respiration (APGAR). Skor pada menit ke-5 terbukti menjadi prediktor kuat untuk menilai kelangsungan hidup neonatal, termasuk prediktor terhadap asfiksia dan morbiditas neonatal terkait asfiksia berat. ${ }^{7}$ Dibandingkan dengan skor APGAR normal pada menit ke-5 (7-10), skor yang rendah (0-3 atau 4-6) berkaitan dengan risiko relatif tinggi terhadap kematian dini. $^{8}$

Subjek penelitian dipilih berdasarkan data rekam medik pasien preeklamsia di Departemen Obstetri dan Ginekologi RSUP Dr. Hasan Sadikin Bandung selama periode penelitian dan memenuhi kriteria inklusi (pasien dengan diagnosis preeklamsia, baik diberikan atau tanpa diberikan terapi antihipertensi sebelum menjalani persalinan di RSUP Dr. Hasan Sadikin Bandung dan memiliki data rekam medik lengkap), dan bebas dari kriteria eksklusi (pasien preeklamsia yang mengalami kematian maternal dan/atau neonatal pasca terminasi kehamilan atau pasien dengan data rekam medik tidak lengkap).

Analisis data meliputi analisis deskriptif dan statistik yang diolah menggunakan software IBM SPSS 24.0. Uji normalitas dilakukan menggunakan uji KolmogorovSmirnov. Hubungan antarvariabel dianalisis menggunakan uji One-way ANOVA dan uji Kruskal-Wallis. Kriteria kebermaknaan dinyatakan dengan nilai $\mathrm{p}$ (sebesar 5\% atau 0,05) dan interval kepercayaan (IK) sebesar 95\%. Penelitian ini mendapatkan persetujuan dari Komite Etik Penelitian Kesehatan RSUP Dr. Hasan Sadikin Bandung dengan nomor LB.02.01/X.6.5/93/2019.

\section{Hasil}

Pada penelitian ini, terdapat sebanyak 274 pasien preeklamsia rawat inap selama tahun 2018, dengan 60 rekam medik pasien tidak dapat tertelusur dan 92 pasien dengan kriteria eksklusi (14 pasien tanpa partus; 10 pasien tanpa data skor APGAR; 5 pasien rawat konservatif pascapartus di rumah sakit lain; 1 tanpa keterangan diagnosis preeklamsia; 1 kematian maternal; dan 1 kematian neonatal). Total 182 pasien memenuhi kriteria inklusi.

Tabel 1 menunjukkan beberapa karakteristik pasien yang diduga menjadi faktor predisposisi terhadap kejadian preeklamsia, antara lain usia maternal, usia gestasi, jumlah paritas, jenis partus, riwayat hipertensi, dan riwayat penyakit/komorbid lain. Distribusi jumlah pasien yang melahirkan pada usia kehamilan $<37$ minggu/preterm (89 subjek/48,9\%) dibandingkan pasien yang melahirkan pada usia kehamilan antara 37-42 minggu/aterm (93 subjek/51,1\%) tidak memiliki perbedaan berarti. Terdapat 87 subjek (47,8\%) multipara (wanita yang telah melahirkan anak $>1$ kali). Jumlah ini sedikit lebih tinggi dibandingkan pasien primipara (wanita yang baru melahirkan seorang anak) sebanyak 82 subjek $(45,1 \%)$. Jenis partus tertinggi yaitu melalui bedah sesar (58,2\% dari total subjek). 27 pasien $(14,8 \%)$ dengan riwayat hipertensi sebelum dan selama kehamilan. Peningkatan tekanan darah terjadi pada sebagian besar pasien, sisanya menunjukkan gejala preeklamsia lain 
(Proteinuria, sindrom haemolysis, elevated liver enzymes, low platelet count (HELLP), gangguan ginjal dan hati, fetal growth restriction/FGR, dan trombositopenia). Tabel 2 menunjukkan distribusi kelompok usia 2035 tahun, kelompok paritas multipara, dan diagnosis preeklamsia berat adalah kelompok terbanyak dengan insidensi BBLR dan asfiksia.

Tekanan darah pasien dibedakan menjadi dua, yaitu tekanan darah saat masuk dan saat keluar rumah sakit. Hasil analisis menunjukkan perbedaan tekanan darah sistolik dan diastolik yang bermakna antara saat masuk dan keluar rumah sakit. Pemberian terapi antihipertensi pada setiap kelompok memberikan perbaikan tekanan darah secara nyata.

Tabel 3 menunjukkan metildopa sebagai antihipertensi terbanyak yang digunakan oleh pasien $(95,9 \%)$. Penggunaan metildopa tersebut berupa tunggal maupun kombinasi, tergantung pada kondisi pasien, respon terapi, dan komorbid. Dari semua antihipertensi yang diresepkan, tidak terdapat obat kategori
$\mathrm{X}$ (dengan kontraindikasi). Kombinasi terapi antihipertensi dengan aksi kerja berbeda dan dosis minimal dibutuhkan untuk menormalkan tekanan darah terutama mencegah komplikasi.

Data berat badan berdistribusi normal $(p=0,158)$. Secara statistik, rata-rata berat badan bayi pada kelompok yang diberi antihipertensi $<2500$ gr, sedangkan kelompok tanpa terapi antihipertensi, memiliki rata-rata $>2500$ gr (Tabel 4). Ini menunjukkan bahwa pasien yang mendapat terapi antihipertensi memiliki kecenderungan terhadap kejadian BBLR. Tidak terdapat perbedaan bermakna antara rata-rata berat badan bayi pada semua kelompok terapi antihipertensi ( $\mathrm{p}>0,05$; IK95\%) (Tabel 5). Ini menunjukkan di antara keempat kelompok terapi, tidak ada perbedaan kecenderungan terhadap kejadian BBLR. Jika ditarik proporsi, kelompok kombinasi metildopa+antihipertensi lain memberikan proporsi tertinggi $(75,0 \%)$ sehingga paling memberikan kecenderungan terhadap insidensi BBLR dibandingkan kelompok lainnya.

Tabel 1 Distribusi Karakteristik Pasien Preeklamsia

\begin{tabular}{lcc}
\hline \multicolumn{1}{c}{ Karakteristik } & Jumlah $(\mathbf{n}=\mathbf{1 8 2})$ & Persentase $(\mathbf{\%})$ \\
\hline Usia Pasien & 27 & 14,8 \\
$<20$ tahun & 116 & 63,7 \\
$20-35$ tahun & 39 & 21,4 \\
$>35$ tahun & & 48,9 \\
Usia Gestasi & 89 & 51,1 \\
$<37$ minggu (preterm) & 93 & 45,1 \\
$37-42$ minggu (aterm) & & 47,8 \\
Jumlah Paritas & 82 & 7,1 \\
Primipara & 87 & 11,0 \\
Multipara & 13 & 30,8 \\
Grande-multipara & & 58,2 \\
Jenis Partus & 20 & \\
Normal spontan & 56 & 14,8 \\
Normal dengan bantuan (induksi, vakum, forsep) & 106 & 85,2 \\
Bedah sesar & & 24,7 \\
Riwayat Hipertensi & 27 & 75,3 \\
Dengan riwayat hipertensi & 155 & \\
Tanpa riwayat hipertensi & 45 & \\
Komorbiditas & 137 & \\
Dengan komorbid/faktor penyulit & & \\
Tanpa komorbid/faktor penyulit & & \\
\hline
\end{tabular}


Tabel 2 Distribusi Usia Maternal, Paritas, dan Diagnosis terhadap BBLR dan Skor APGAR

\begin{tabular}{|c|c|c|c|c|c|c|c|c|}
\hline \multirow{3}{*}{ Usia Maternal } & \multicolumn{4}{|c|}{ BBLR } & \multicolumn{4}{|c|}{ Skor APGAR } \\
\hline & \multicolumn{2}{|c|}{ Ya } & \multicolumn{2}{|c|}{ Tidak } & \multicolumn{2}{|c|}{$<7$} & \multicolumn{2}{|c|}{$\geq 7$} \\
\hline & $\mathbf{N}$ & $\%$ & $\mathbf{N}$ & $\%$ & $\mathbf{N}$ & $\%$ & $\mathbf{N}$ & $\%$ \\
\hline$<20$ tahun $(\mathrm{n}=27)$ & 12 & 44,4 & 15 & 55,6 & - & - & 27 & 100,0 \\
\hline $20-35$ tahun $(n=116)$ & 67 & 57,8 & 49 & 42,2 & 16 & 13,8 & 100 & 86,2 \\
\hline$>35$ tahun $(\mathrm{n}=39)$ & 22 & 56,4 & 17 & 43,6 & 6 & 15,4 & 33 & 84,6 \\
\hline \multicolumn{9}{|l|}{ Paritas } \\
\hline Primipara $(n=82)$ & 45 & 54,9 & 37 & 45,1 & 4 & 4,9 & 78 & 95,1 \\
\hline Multipara $(\mathrm{n}=87)$ & 52 & 40,2 & 35 & 40,2 & 16 & 18,4 & 71 & 81,6 \\
\hline Grande-multipara $(n=13)$ & 4 & 30,8 & 9 & 69,2 & 2 & 15,4 & 11 & 84,6 \\
\hline \multicolumn{9}{|l|}{ Diagnosis } \\
\hline Preeklamsia $(\mathrm{n}=5)$ & 2 & 40,0 & 3 & 60,0 & - & - & 5 & 100,0 \\
\hline Preeklamsia berat $(n=168)$ & 92 & 54,8 & 76 & 45,2 & 21 & 12,5 & 147 & 87,5 \\
\hline Eklamsia $(\mathrm{n}=9)$ & 7 & 77,8 & 2 & 22,2 & 1 & 11,1 & 8 & 88,9 \\
\hline
\end{tabular}

Data skor APGAR berdistribusi tidak normal $(\mathrm{p}=0,000)$. Secara statistik, tidak terdapat perbedaan skor APGAR yang bermakna antara kelompok yang diberi terapi dengan kelompok tanpa terapi antihipertensi (Tabel 4). Tidak terdapat perbedaan skor APGAR yang bermakna antarkelompok terapi antihipertensi ( $\mathrm{p}>0,05$; IK95\%) (Tabel 6). Hal ini menunjukkan di antara keempat kelompok terapi, tidak terdapat perbedaan kecenderungan terhadap kejadian asfiksia. Jika ditarik proporsi, kelompok kombinasi metildopa+antihipertensi lain memberikan proporsi tertinggi $(17,9 \%)$ sehingga paling memberikan kecenderungan terhadap insidensi asfiksia dibandingkan kelompok lainnya.

\section{Pembahasan}

Pilihan terapi antihipertensi pada pasien HDK didasarkan pada pengalaman dan pengetahuan dasar praktisi, efek samping, kontraindikasi, ketersediaan obat, serta biaya. ${ }^{6}$ Metildopa, labetalol, nifedipin, nikardipin, dan hidralazin adalah obat yang direkomendasi. Golongan angiotensin receptor blocker dan inhibitor

Tabel 3 Daftar Penggunaan Antihipertensi pada Pasien Preeklamsia di Instalasi Rawat Inap RS Hasan Sadikin Tahun 2018

\begin{tabular}{lccc}
\hline \multicolumn{1}{c}{ Antihipertensi } & Kategori Keamanan (FDA) & Jumlah Pasien (n=170) & Persentase (\%) \\
\hline Metildopa & $\mathrm{B}$ & 163 & 95,9 \\
Nifedipin & $\mathrm{C}$ & 70 & 41,2 \\
Amlodipin & $\mathrm{C}$ & 21 & 12,4 \\
Furosemid & $\mathrm{C}$ & 8 & 4,7 \\
Nikardipin & $\mathrm{C}$ & 7 & 4,1 \\
Spironolakton & $\mathrm{C}$ & 1 & 0,6 \\
\hline
\end{tabular}

Tabel 4 Perbandingan Rata-Rata Berat Badan Bayi dan Skor APGAR antara Kelompok Terapi dengan Kelompok Tanpa Terapi Antihipertensi

\begin{tabular}{lcccc}
\hline \multicolumn{1}{c}{ Terapi Preeklamsia $(\mathbf{n}=\mathbf{1 8 2})$} & Rata-Rata BB \pm s.b & Nilai $\mathbf{p} *$ & Skor APGAR & Nilai $\mathbf{p} * *$ \\
\hline Dengan Antihipertensi $(\mathrm{n}=170)$ & $2227 \mathrm{~g} \pm 779,8$ & 0,044 & $9(1-10)$ & 0,070 \\
Tanpa Antihipertensi $(\mathrm{n}=12)$ & $2696 \mathrm{~g} \pm 667,2$ & & $9(8-10)$ & \\
*Uji t tidak berpasangan; **Uji Mann-Whitney & &
\end{tabular}


Tabel 5 Perbandingan Penggunaan Antihipertensi terhadap Insidensi BBLR beserta Proporsinya

\begin{tabular}{|c|c|c|c|c|}
\hline \multirow{3}{*}{$\begin{array}{l}\text { Terapi Antihipertensi } \\
\qquad(\mathrm{n}=170)\end{array}$} & \multicolumn{2}{|c|}{$\begin{array}{c}\text { Perbandingan Rata-Rata Berat } \\
\text { Badan Bayi Antarkelompok } \\
\text { Antihipertensi }\end{array}$} & \multirow{2}{*}{\multicolumn{2}{|c|}{$\begin{array}{c}\text { Proporsi antara Kelompok } \\
\text { Antihipertensi terhadap } \\
\text { Insidensi BBLR }\end{array}$}} \\
\hline & \multirow{2}{*}{ Rata-Rata $\mathbf{B B} \pm \mathbf{s . b}$} & \multirow{2}{*}{ Nilai-p* } & & \\
\hline & & & BBLR & Tidak BBLR \\
\hline Metildopa $(n=80)$ & $2334 \mathrm{~g} \pm 722,5$ & \multirow{4}{*}{0,051} & $39(50,0)$ & $39(50,0)$ \\
\hline Metildopa + Nifedipin $(n=58)$ & $2214 \mathrm{~g} \pm 791,2$ & & $34(59,6)$ & $23(40,4)$ \\
\hline Metildopa + Antihipertensi lain ${ }^{\mathrm{a}}(\mathrm{n}=25)$ & $1855 \mathrm{~g} \pm 804,5$ & & $21(75,0)$ & $7(25,0)$ \\
\hline Antihipertensi lain $^{\mathrm{a}}(\mathrm{n}=7)$ & $2439 \mathrm{~g} \pm 968,1$ & & $4(57,1)$ & $3(42,9)$ \\
\hline
\end{tabular}

BBLR=Berat Badan Lahir Rendah; *Uji One-way ANOVA; ${ }^{a}$ Antihipertensi lain: Amlodipin, nikardipin, furosemid, spironolakton

Tabel 6 Perbandingan Penggunaan Antihipertensi terhadap Insidensi Asfiksia beserta Proporsinya

\begin{tabular}{|c|c|c|c|c|}
\hline \multirow{3}{*}{$\begin{array}{l}\text { Terapi Antihipertensi } \\
\qquad(\mathrm{n}=\mathbf{1 7 0})\end{array}$} & \multicolumn{2}{|c|}{$\begin{array}{l}\text { Perbandingan Skor APGAR } \\
\text { Antarkelompok Antihipertensi }\end{array}$} & \multirow{2}{*}{\multicolumn{2}{|c|}{$\begin{array}{c}\text { Proporsi antara Kelompok } \\
\text { Antihipertensi terhadap } \\
\text { Insidensi Asfiksia }\end{array}$}} \\
\hline & \multirow{2}{*}{ Skor APGAR } & \multirow{2}{*}{ Nilai-p* } & & \\
\hline & & & Asfiksia & Tidak Asfiksia \\
\hline Metildopa $(\mathrm{n}=80)$ & $9(3-10)$ & \multirow{4}{*}{0,094} & $7(9,0)$ & $71(91,0)$ \\
\hline Metildopa + Nifedipin $(\mathrm{n}=58)$ & $9(1-10)$ & & $9(15,8)$ & $48(84,2)$ \\
\hline Metildopa + Antihipertensi lain ${ }^{\mathrm{a}}(\mathrm{n}=25)$ & $8(1-9)$ & & $5(17,9)$ & $23(82,1)$ \\
\hline Antihipertensi lain ${ }^{\mathrm{a}}(\mathrm{n}=7)$ & $8(4-9)$ & & $1(14,3)$ & $6(85,7)$ \\
\hline
\end{tabular}

*Uji Kruskal-Wallis; ${ }^{a}$ Antihipertensi lain: Amlodipin, nikardipin, furosemid, spironolakton

renin tidak direkomendasikan selama masa kehamilan. The American College of Obstetricians and Gynecologists (ACOG) menyarankan untuk tidak menggunakan antagonis reseptor mineralokortikoid selama kehamilan. ${ }^{6,9}$

Manfaat dan risiko antihipertensi pada hipertensi ringan-sedang (tekanan darah 140/90-169/109 $\mathrm{mmHg}$ ) masih tergolong kontroversial. Menurut Perkumpulan Obstetri dan Ginekologi Indonesia (POGI) tahun 2016 yang tercantum dalam Pedoman Nasional Pelayanan Kedokteran (PNPK), antihipertensi direkomendasikan pada pasien preeklamsia dengan hipertensi berat atau tekanan darah sistolik $\geq 160 \mathrm{mmHg}$ atau diastolik $\geq 110$ $\mathrm{mmHg}$.

Antihipertensi yang diberikan pada kondisi kehamilan diduga menyebabkan beberapa perubahan pada aliran uteroplasenta dan vaskularisasi janin akibat efek relaksasi pembuluh darah. Keadaan hipertensi berat akut berkaitan dengan vasokonstriksi arteriolar dengan penurunan aliran uteroplasenta yang menyebabkan defisit/penurunan suplai oksigen di area pertukaran fetus dan maternal sehingga mengakibatkan hipoksia janin. Pemberian antihipertensi diduga meningkatkan aliran uteroplasenta akibat terjadinya penurunan resistensi pembuluh darah uterin dan penurunan vasokonstriksi. Padahal, penurunan tekanan darah secara tiba-tiba dapat menyebabkan efek sebaliknya, menurunkan aliran uteroplasenta dan memperburuk kondisi intrauterin. Aliran darah uteroplasenta sering menurun pada kondisi HDK, sehingga penting menghindari penggunaan obat-obatan yang menyebabkan penurunan lebih jauh. ${ }^{10}$ Dampak lebih lanjut terganggunya aliran uteroplasenta meliputi hambatan pertukaran gas (oksigen dan 
karbondioksida), nutrien dan elektrolit, serta terhambatnya pertumbuhan janin, seperti BBLR dan gangguan sindrom jalan napas/ asfiksia.

Penelitian cohort dalam jumlah besar menyatakan hipertensi kronis dengan/tanpa pengobatan selama kehamilan merupakan faktor risiko independen yang signifikan dalam memberikan outcome merugikan bagi perinatal, seperti small for gestasional age (SGA), intra uterine growth restriction (IUGR), dan preterm delivery (PTD) jika dibandingkan dengan outcome bayi dari wanita dengan/tanpa hipertensi kronis dan tanpa antihipertensi. Wanita dengan hipertensi kronis yang diberikan atenolol, metildopa atau kombinasinya memiliki tingkat BBLR, SGA, IUGR, dan PTD yang lebih tinggi, bahkan setelah penyesuaian faktor perancu seperti usia ibu, etnis, kebiasaan merokok, diabetes melitus (DM), kehamilan kembar, perawatan prenatal yang kurang, dan paritas. ${ }^{11}$ Hal ini menunjukkan selain karena faktor hipertensi yang dialami, faktor pemberian antihipertensi diduga berpengaruh terhadap outcome bayi.

Perlu dilakukan penelitian lanjutan dengan melibatkan jumlah sampel yang memadai dari berbagai populasi untuk mengetahui hasil perbandingan antarpenggunaan jenis antihipertensi tertentu secara spesifik dan representatif. Penelitian prospektif diperlukan untuk mengamati faktor lain yang memengaruhi kedua insidensi, seperti penggunaan obatobat lain, nutrisi, dan faktor pemeriksaan kehamilan rutin atau antenatal care. Terapi antenatal diperlukan untuk pengendalian tekanan darah, mengenali preeklamsia awal, mencegah eklamsia, dan mengoptimalkan outcome kelahiran bagi ibu dan bayi. ${ }^{12}$

\section{Simpulan}

Tidak terdapat perbedaan bermakna $(\mathrm{p}>0,05$; IK95\%) antara kelompok terapi antihipertensi (metildopa, nifedipin, amlodipin, nikardipin, furosemid, dan spironolakton) baik tunggal maupun kombinasi, dalam memberikan kecenderungan terhadap insidensi BBLR dan asfiksia. Kelompok kombinasi metildopa dan antihipertensi lain (amlodipin, nikardipin, furosemid, dan spironolakton) merupakan kelompok dengan proporsi tertinggi dalam memberi kecenderungan terhadap insidensi BBLR dan asfiksia.

\section{Pendanaan}

Penelitian ini tidak didanai oleh sumber hibah manapun.

\section{Konflik Kepentingan}

Seluruh penulis menyatakan tidak terdapat potensi konflik kepentingan dengan penelitian, kepenulisan (authorship), dan atau publikasi artikel ini.

\section{Daftar Pustaka}

1. Centre for Maternal and Child Enquiries (CMACE). Saving mothers' lives: Reviewing maternal deaths to make motherhood safer: 2006-08. The eighth report on confidential enquiries into maternal deaths in the United Kingdom. BJOG. 2011;118(1):1-203. doi: 10.1111/j .1471-0528.2010.02847.x

2. Cunningham FG, Leveno KJ, Bloom SL, Dashe J, Hoffman BL, Casey BM, et al. Williams obstetrics, $24^{\text {th }}$ edition. New York: McGraw-Hill Education; 2014.

3. Steegers EAP, von Dadelszen P, Duvekot JJ, Pijnenborg R. Pre-eclampsia. Lancet. 2010;376(9741):631-44. doi: 10.1016/S0 140-6736(10)60279-6

4. Antonucci R, Porcella A, Pilloni MD. Perinatal asphyxia in the term newborn. J Pediatr Neonat Individual Med. 2014;3 (2):e030269. doi: 10.7363/030269

5. Kernaghan D, Duncan AC, McKay GA. 
Hypertension in pregnancy: A review of therapeutic options. Obstet Med. 2012; 5(2):44-9. doi: 10.1258/om.2011.110061

6. The American College of Obstetricians and Gynecologists (ACOG). Hypertension in pregnancy. Washington DC: ACOG; 2013.

7. Cnattingius S, Norman M, Granath F, Petersson G, Stephansson. Apgar score components at 5 minutes: Risks and prediction of neonatal mortality. Paediatr Perinat Epidemiol. 2017;31(4):328-37. doi: 10.1111/ppe. 12360

8. Iliodromiti S, Mackay DF, Smith GC, Pell JP, Nelson. APGAR score and the risk of cause specific infant mortality: A population based cohort study of 1,029,207 livebirths. Lancet. 2014;384 (9956):1749-55. doi: 10.1016/S0140-67 36(14)61135-1

9. Magee LA, Dadelszen P, Rey E, Ross $\mathrm{S}$, et al. Less-tight versus tight control of hypertension in pregnancy. $\mathrm{N}$ Engl $\mathrm{J}$ Med. 2015;372(5):407-17. doi: 10.1056/ NEJMoa1404595

10. Gainder S, Thakur M, Saha SC, Prakash M. To study the changes in fetal hemodynamics with intravenous labetalol or nifedipine in acute severe hypertension. Pregnancy Hypertens. 2019;15:12-5. doi: 10.1016/j.preghy.2018.02.011

11. Orbach H, Matok I, Gorodischer R, Sheiner E, Daniel S, Wiznitzer A, et al. Hypertension and antihypertensive drugs in pregnancy and perinatal outcomes. Am J Obstet Gynecol. 2013;208(4):301.e1-6. doi: 10.1016/j.ajog.2012.11.011

12. Duley L, Gulmezoglu AM, HendersonSmart DJ, Chou D. Magnesium sulphate and other anticonvulsants for women with pre-eclampsia. Cochrane Database Syst Rev. 2010;2010(11):CD000025. doi: 10.1002/14651858.CD000025.pub2 